\title{
Identification of Micro-Earthquake Hypocenters using Geiger and Coupled Velocity-Hypocenters Methods
}

\author{
Widya Utama ${ }^{\mathrm{a}, 1}$, Dwa Desa Warnana ${ }^{\mathrm{a}, 2}$, Sherly Ardhya Garini ${ }^{\mathrm{a}, 3}$ \\ ${ }^{a}$ Geophysical Engineering Department, Institut Teknologi Sepuluh Nopember (ITS), Surabaya, 60111, Indonesia \\ Corresponding author: ${ }^{1}$ widya@geofisika.its.ac.id, ${ }^{2} d w a \_d e s a @ g e o f i s i k a . i t s . a c . i d,{ }^{3}$ sherly.ardhyagarini@gmail.com
}

\begin{abstract}
The accuracy location of hypocenter is needed to determine the subsurface character beneath a geothermal area. The study used 73 micro-earthquake events; each micro-earthquake event was classified based on the time difference between the $P$ and $S$ waves (ts-tp) that had values $\leq 3$ seconds, the magnitude of micro-earthquake $\leq 3 \mathrm{SR}$ and each micro-earthquake event was recorded at least by 3 observer stations. We inverted selected $P$ and $S$ travel times from 11-unit seismic stations on $X$ geothermal area. The initial hypocenter location was determined using Geiger method. The result of the Geiger method's initial hypocenter location was then used as the input to determine the accurate hypocenter location in the following method, Coupled Velocity-Hypocenters method. Other parameters were also used on this second method, including hypocenter location, 1-D velocity model, origin time, vp/vs ratio, zshift and the station correction. The distribution of hypocenter locations of micro-earthquakes obtained using the second method was better than the results from Geiger method. This result is supported by the Coupled Velocity-Hypocenters average RMS error value, which was smaller, only 0.19 seconds, compared to the Geiger method, which had an average RMS error of 0.74 seconds. The hypocenter location of the relocation was more clustered in the reservoir area, precisely in the production well, and in the heat source area. The hypocenter location in the production well area indicates fluid flow through the fracture from the permeable zone.
\end{abstract}

Keywords - Coupled velocity-hypocenters; geiger; geothermal; hypocenter; micro-earthquake

Manuscript received 9 Dec. 2019; revised 27 Nov. 2020; accepted 11 Dec. 2020. Date of publication 28 Feb. 2021. IJASEIT is licensed under a Creative Commons Attribution-Share Alike 4.0 International License.

\section{INTRODUCTION}

Micro-earthquake method is one of the geophysical methods used to represent small earthquakes with magnitudes $\leq 3 \mathrm{ML}[1]$. In general, several factors cause micro-earthquakes in geothermal fields, including:

- The existence of a weak zone that is open or shifted due to water injection thereby increasing the pressure on the rock;

- Coldwater contact with high-temperature igneous rocks (heat source);

- Reduced pore pressure results in the closing of reservoir rock pores due to loss of rock pore filler fluid (due to fluid production).

Analysis of micro-earthquake data begins by identifying the arrival time of Primary waves (P) and waves (S) based on hypocenter wave data recorded on three components by the recording station (seismometer). The $\mathrm{P}$ wave is a hypocenter wave that is first recorded by a seismometer and experiences the earliest frequency changes. At the time of the initial frequency change, the $\mathrm{P}$ wave arrival time is determined. For the $\mathrm{S}$ wave arrival time, the waves that undergo a greater frequency change after $\mathrm{P}$ waves experience frequency attenuation [2].

The inversion method is used in seismology because the recording is not possible directly under the earth's surface. The inversion process is a field data processing that involves mathematical and statistical settlement techniques to obtain useful information about the distribution of physical properties below the surface. The purpose of the inversion process is to estimate the rock's physical parameters that were not previously known. Examples of inversion problems in the field of geophysics are the determination of underground structures, estimation of parameters of mining materials, estimation of parameters of accumulation of energy sources, and determination of earthquake locations based on the arrival time of the hypocenter waves [1]-[4].

Several inversion methods have been successfully developed to extract earthquake parameter information and earthquake velocity structure from a set of earthquake wave arrival time data. Since then, theoretically and technically, the structure of earthquake wave velocity below the earth's 
surface can be determined by inverting a set of data on the arrival time of earthquake waves recorded on a seismogram [5], [6].

One method for identifying hypocenter locations (epicenter and depth) is the Geiger method. This method identified the location of single hypocenter by counting the residual times between observation and calculation time. The results of determining the location of micro-earthquake hypocenter using the Geiger method are more following the geological state data (closer to the source, i.e., faults and volcanoes) compared to using the three-circle method. However, calculations using these methods generally still contain errors from unmodeled hypocenter wave velocity structures [7]. Therefore, the weakness of the method requires an update of the 1-D wave velocity structure model.

One of the location test methods that can update the velocity model is the Coupled Velocity-Hypocenters method. This method is an earthquake location test method which applies station corrections simultaneously using the Geiger method principle. In this method, the velocity model is tested by applying the Kissling equation [7]. Unmodeled hypocenter wave velocity structures can be overcome by location test and modelling of 1-D P wave velocity using the Coupled Velocity-Hypocenters method through the Kissling equation [1]-[3], [8], [9]. The location test results using Coupled Velocity-Hypocenters method obtained a new 1-D velocity model with different $\mathrm{vp} / \mathrm{vs}$ in each layer [7]. Hypocenters position with a high accuracy becomes important because high hypocenter in an area can represent fractures with high permeability [10]. Besides, fracturing is one of the essential factors in the geothermal reservoir equilibrium system.

Based on this background, the distribution and location of micro-earthquake hypocenter are needed to monitor and evaluate the performance of geothermal reservoirs. Therefore, the position of the hypocenter with high accuracy is an essential factor to determine. In this study, the microearthquake hypocenter's initial location was determined using the Geiger method, which was then used for the initial hypocenter in the location test using the Coupled VelocityHypocenters method.

\section{MATERIAL AND Method}

The hypocenter location test applied the Geiger and Coupled Velocity-Hypocenters method using 73 microearthquake events on $\mathrm{X}$ geothermal area. Each microearthquake event was classified based on micro-earthquake criteria, including the difference between the arrival time of $\mathrm{P}$ and $\mathrm{S}$ waves $\leq 3$ seconds, the magnitude of microearthquake $\leq 3 \mathrm{SR}$, and each micro-earthquake event was recorded at least by three recording stations. The total number of recording stations used in this study was 9. The position of recording station on $\mathrm{X}$ geothermal area is shown as in Fig. 1.

The principle of determining the location of microearthquake hypocenter using the Geiger method is to calculate the residual time or the difference between the observed time and the calculated time. The Geiger method is an inversion method that uses $\mathrm{P}$ and $\mathrm{S}$ waves arrival time data. This method's input parameters include recording station data or seismic station coordinates (codes, coordinates and station elevation value), 1-D of $\mathrm{P}$ waves velocity model, $\mathrm{P}$ and $\mathrm{S}$ waves arrival times data for each micro-earthquake event [3].

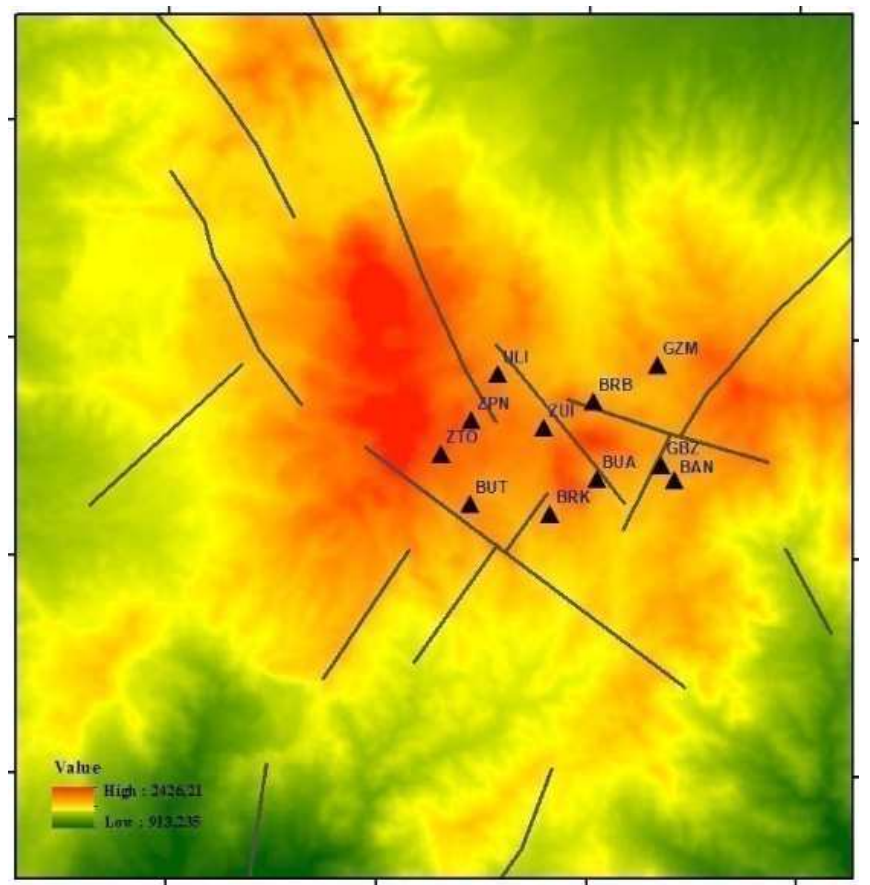

Fig. 1 The position of recording station (seismic station) on $\mathrm{X}$ geothermal area

Micro-earthquake parameters produced by this method include the time of occurrence of the micro-earthquake (origin time), the value of the RMS error, coordinates and depth of the micro-earthquake hypocenter as shown in Fig. 2.

This study's advanced hypocenter location test was the hypocenter location test conducted simultaneously using the Coupled Velocity-Hypocenters method. Coupled VelocityHypocenters method is a travel time inversion method. This study's travel time data is the difference between the wave arrival time and the micro-earthquake occurrence.

Input parameters needed in this method include recording station data or seismic station coordinates (codes, coordinates, and station elevation value), 1-D of $\mathrm{P}$ wave velocity model, $\mathrm{P}$ and $\mathrm{S}$ waves travel time data for each micro-earthquake event, $\mathrm{Vp} / \mathrm{Vs}$ ratio value, and the average elevation (zshift) of recording station or seismic station, as illustrated in Fig. 3

These parameters were processed to produce output parameters and corrected parameters of the location test results using the Coupled Velocity-Hypocenters method. The output parameters consist of micro-earthquake hypocenter location test results (coordinates and depth), RMS error value, GAP value, renewable 1-D of $\mathrm{P}$ waves velocity model and the station correction values. Meanwhile, this method's corrected parameters consist of 1-D of the P wave velocity model, hypocenter location, the corrected value of the station, and the origin time of microearthquakes.

This study's initial velocity model is the 1-D of the $P$ wave velocity model, as shown in Fig. 4. The distribution of micro-earthquake hypocenter locations using both the Geiger method and the Coupled Velocity-Hypocenters method were mapped to then be identified and analyzed. 


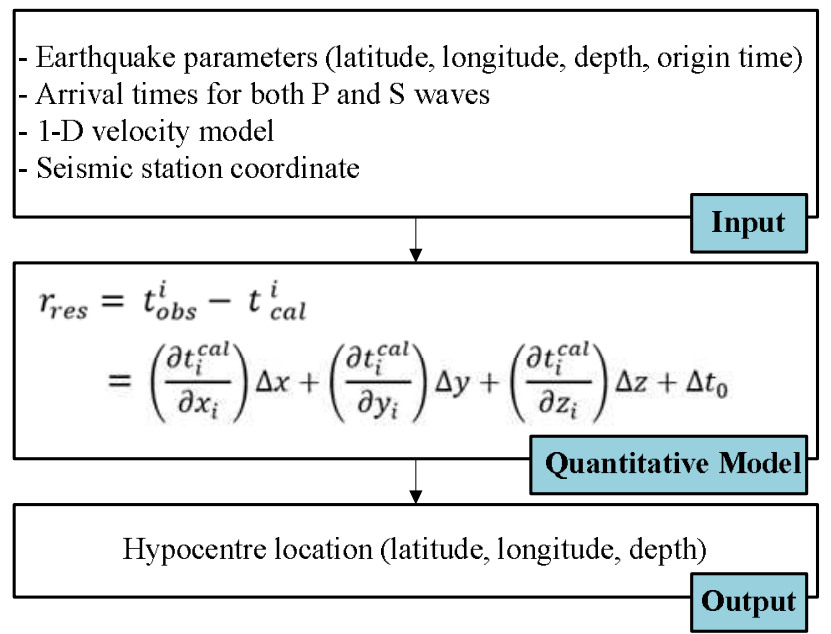

Fig. 2 Schematic of determination initial hypocenter location for microearthquakes using the Geiger method [11]

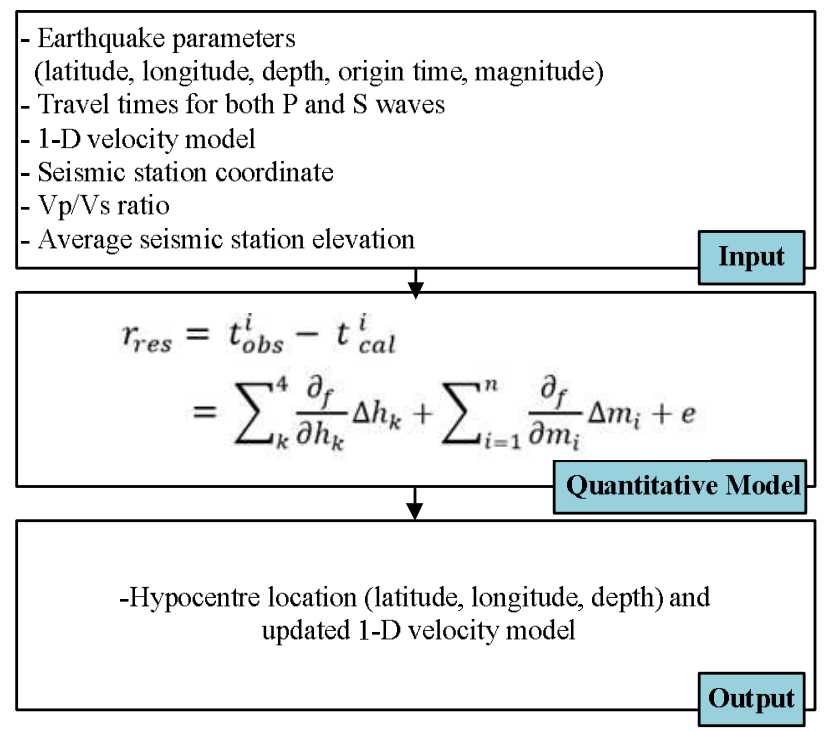

Fig. 3 Schematic of micro-earthquakes hypocenter location test using the Coupled Velocity-Hypocenters method [12]

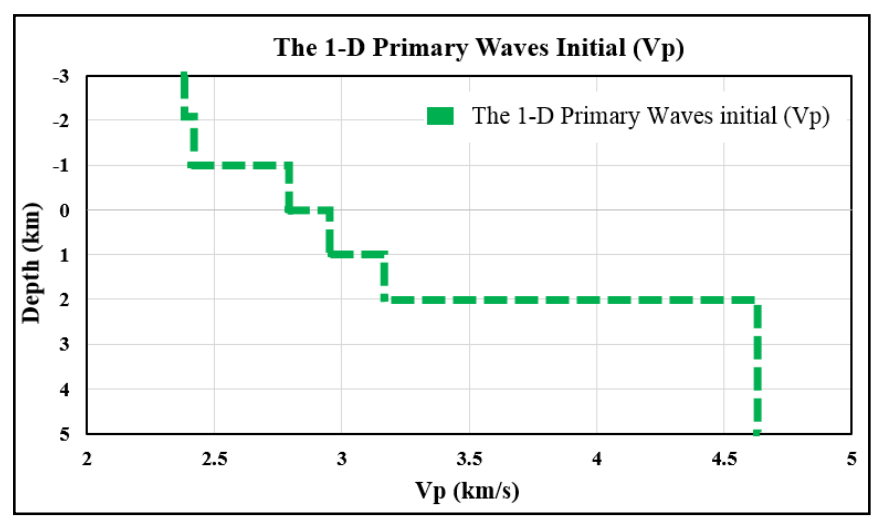

Fig. 4 The 1-D Primary (P) waves velocity initials model of research

\section{RESULTS AND DISCUSSION}

The results of the hypocenter location test using Geiger Method and Coupled Velocity-Hypocenter method are given below:

\section{A. Micro-Earthquake Hypocenters Location Result using Geiger Method}

This study used 73 micro-earthquake events from 9 recording stations on $\mathrm{X}$ geothermal area. Each earthquake event has been classified based on micro-earthquake criteria including the difference between the arrival time of $\mathrm{P}$ and $\mathrm{S}$ waves $\leq 3$ seconds, the magnitude of micro-earthquake $\leq 3$ $\mathrm{SR}$, and each micro-earthquake event was recorded at a minimum by three recording stations. The value of microearthquake magnitude in this study was calculated using the equation result. [13]. Fig. 5 shows the distribution of micro-earthquakes epicenter locations on $\mathrm{X}$ geothermal area, which was determined using the Geiger method.

A total of 73 micro-earthquake epicenter locations were concentrated northwest-southeast with $69 \%$ of the epicenter concentrated in the well area (production and injection) represented by a blue square and the recording station represented by a red triangle as shown in Fig. 5., whereas, another $31 \%$ of micro-earthquake epicenters were concentrated around local faults in the northwestsoutheastern study area.

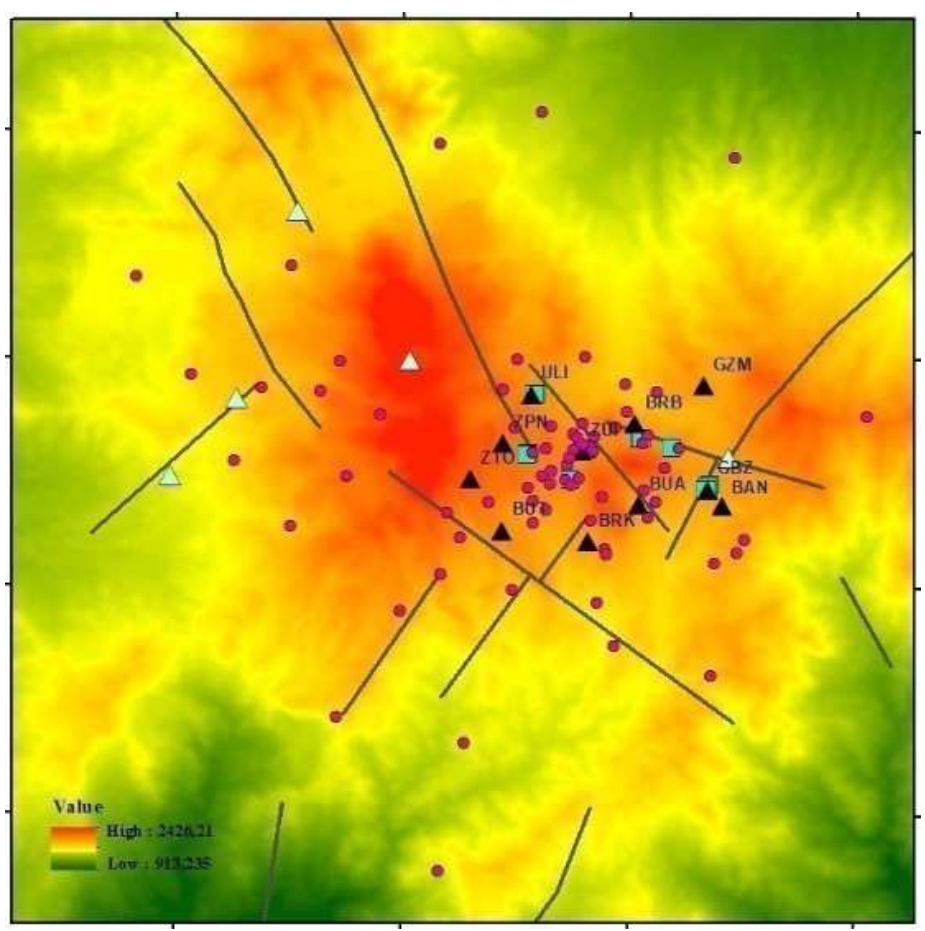

Fig. 5 The distribution of micro-earthquake epicenter locations on $\mathrm{X}$ geothermal area was determined using the Geiger method

The hypocenter distribution variation of micro-earthquake results from the determination using the Geiger method also varied considerably between $-2 \mathrm{~km}$ to $17.85 \mathrm{~km}$ MSL, which is shown in Fig. 6 and Fig. 7.

If we look at Fig. 8, $53.4 \%$ of the micro-earthquake hypocenters are concentrated at a depth of $-1.0 \mathrm{~km}$ above sea level to $0.5 \mathrm{~km}$ below sea level.

The results of determining the initial micro-earthquake hypocenter location using this method show that each event had an RMS error value. The resulting RMS error varied between 0.05 seconds to 19.54 seconds, with an average RMS error of 0.74 seconds. Five micro-earthquake events have an RMS error value $>1$ second, which is shown in Fig.9. 
The large RMS error value was influenced by the arrival time's value and the velocity model used. Furthermore, the micro-earthquake results from the determination using the Geiger method were used as the initial hypocenter location in the advanced hypocenter location test using the Coupled Velocity-Hypocenters method.

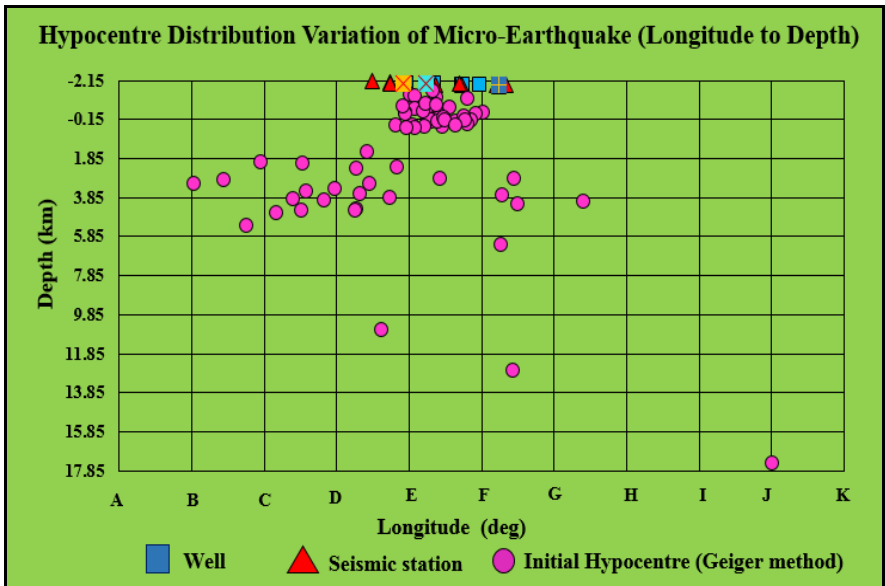

Fig. 6 Hypocenters distribution variations of micro-earthquakes (longitude to depth) on X geothermal area determined using the Geiger method

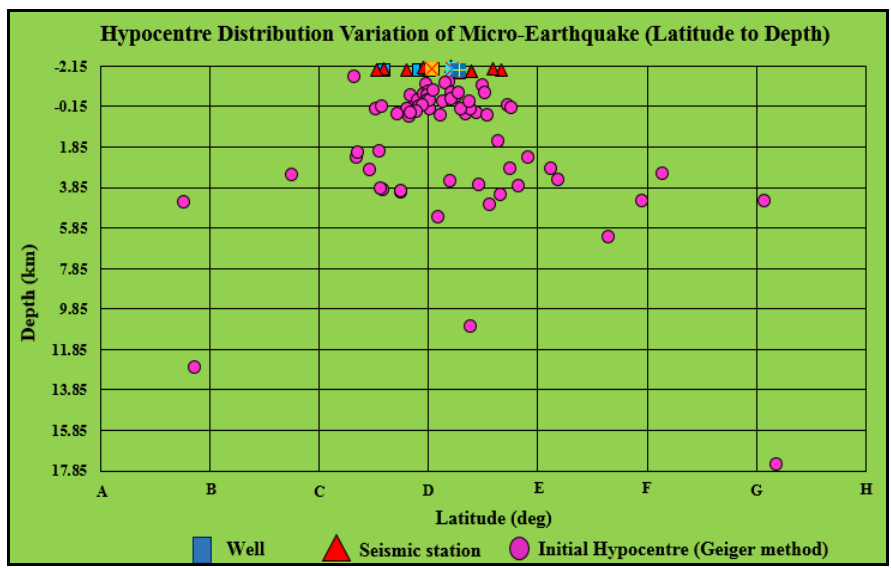

Fig. 7 Hypocenters distribution variations of micro-earthquakes (latitude to depth) on X geothermal area determined using the Geiger method

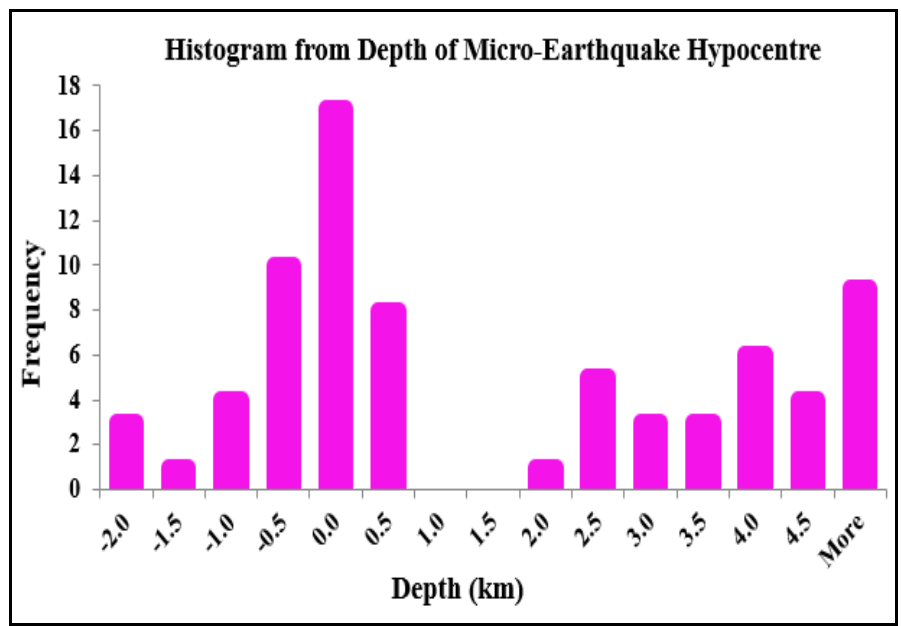

Fig. 8 Histogram depth of micro-earthquake hypocenter determined using the Geiger method

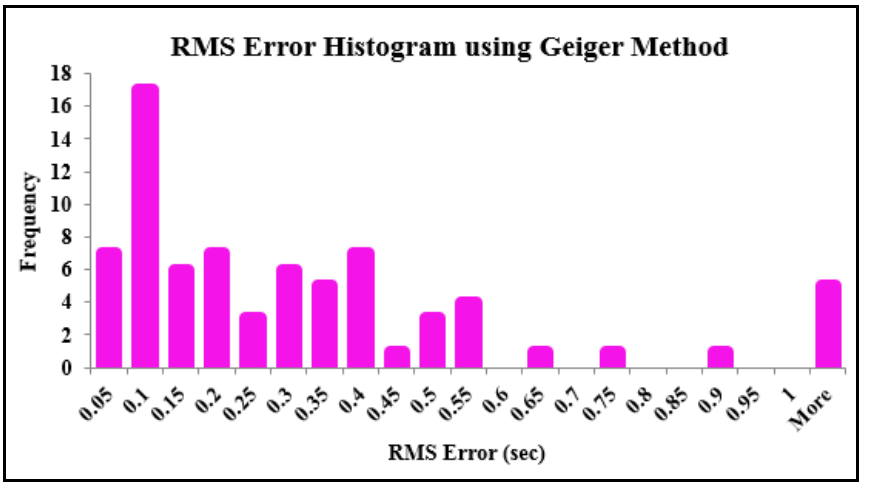

Fig. 9 RMS error histogram of micro-earthquake hypocenter determined using the Geiger method

\section{B. Micro-Earthquake Hypocenters Location Test Result using Coupled Velocity-Hypocenters Method}

The 1-D of the $\mathrm{P}$ wave velocity model used in the location test using this method will be updated in every iteration. Also, in each iteration, the RMS error value will be listed between the observation and calculation travel time data, so that the number of iterations can be adjusted to meet the expected RMS error criteria $(<1$ second). The initial hypocenters location data used was derived from the hypocenters location's determination using the Geiger method. This method no longer uses $\mathrm{P}$ and $\mathrm{S}$ waves' arrival times but uses the $\mathrm{P}$ and $\mathrm{S}$ waves travel times instead. These $\mathrm{P}$ and $\mathrm{S}$ waves travel times represent the difference between the arrival time of both $\mathrm{P}$ and $\mathrm{S}$ waves with the time of the earthquake. This location test uses a 1-D Primary $(\mathrm{P})$ waves velocity initials area results from previous location tests conducted by previous research ([14],[15]). The corrected parameters include the recording station correction, the velocity model, and the earthquake occurrence time. The micro-earthquake hypocenters coordinates used in this study are the results of previous studies by previous research ([14], [15]). This study also added several other correction parameters such as the value of the magnitude for each micro-earthquake event, the value of the ratio $\mathrm{vp} / \mathrm{vs}$ and the average elevation (zshift) of recording station or seismic station.

$\mathrm{Vp} / \mathrm{vs}$ ratio values are obtained using the Wadati diagram. The Wadati diagram is a diagram of the travel time of the $\mathrm{S}$ waves against the travel time of the $\mathrm{P}$ waves. The Wadati diagram is used to determine the trend $\mathrm{vp} / \mathrm{vs}$ of the study area [16]. The Wadati diagram shows the value of the vp/vs trend of this study area of 1.29. Based on the value of the $\mathrm{vp} / \mathrm{vs}$ ratio, it can be identified that this area is an area with vapor dominance. In addition to the $\mathrm{vp} / \mathrm{vs}$ ratio's value, correction of the hypocenters depth reference point must also be considered by adding the zshift value. Zshift relates to the reference to the assessment of the depth of the hypocenter [12]. In the initial micro-earthquake hypocenter location determination method using the Geiger method, the hypocenter depth assessment reference relates to the average elevation of the seismic station. Therefore, the zshift value must be added by finding the average value of the recording station elevation, so that the reference for the microearthquake hypocenter depth assessment using the Coupled Velocity-Hypocenters method becomes relative to the average sea level. In determining the position of the initial 
hypocenter using the Geiger method, the elevation value at each recording station must be given a negative symbol, and then the zshift value must also be negative so that the depth assessment reference remains consistent.

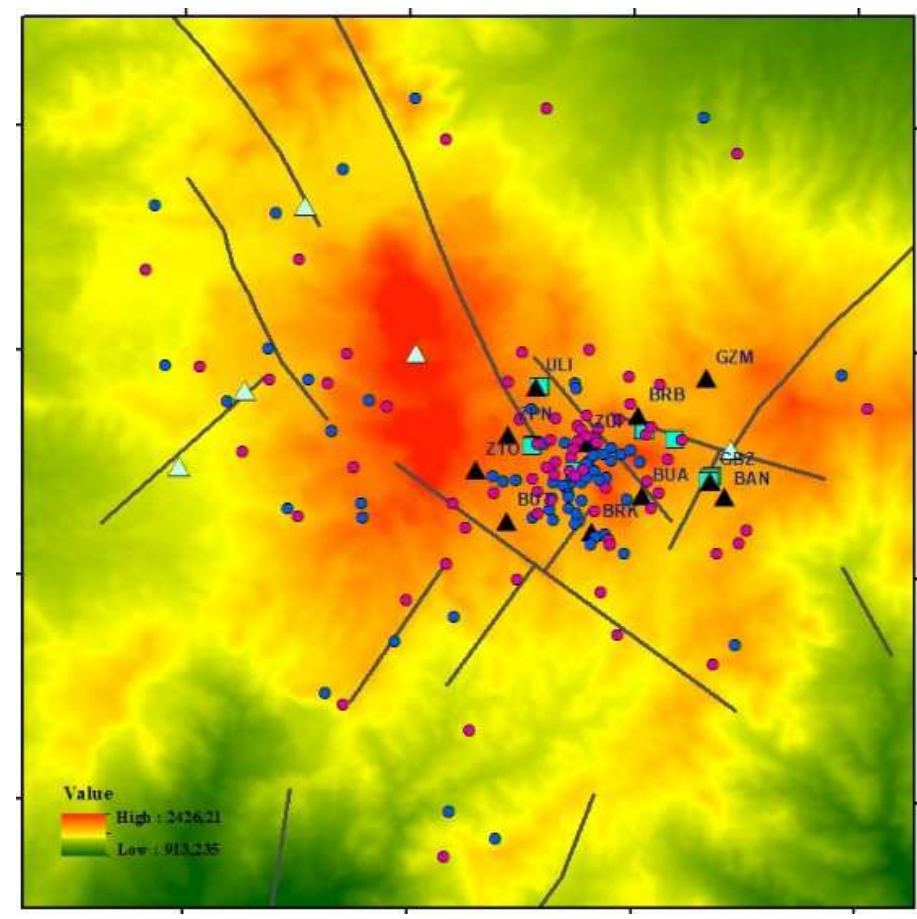

Fig. 10 The distribution of micro-earthquake epicenter locations test on $\mathrm{X}$ geothermal area was determined using the Coupled Velocity-Hypocenters method

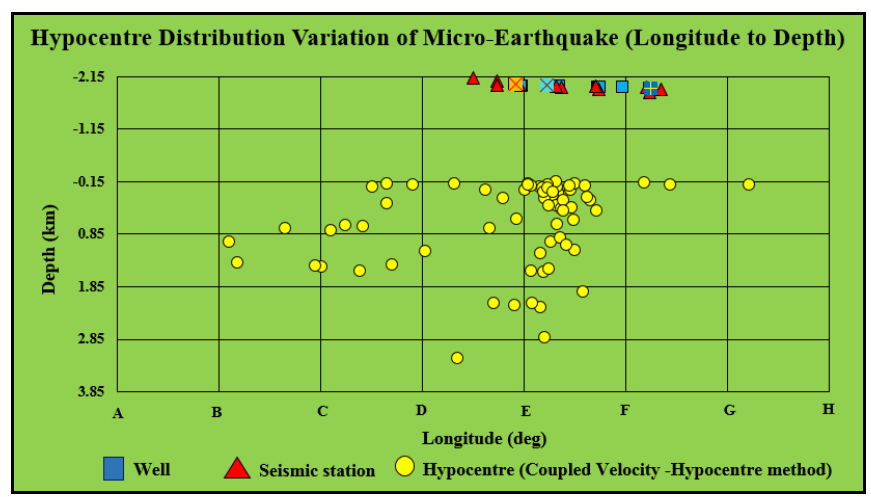

Fig. 11 Hypocenters distribution variations of micro-earthquakes (longitude to depth) on $\mathrm{X}$ geothermal area determined using the Coupled VelocityHypocenters method

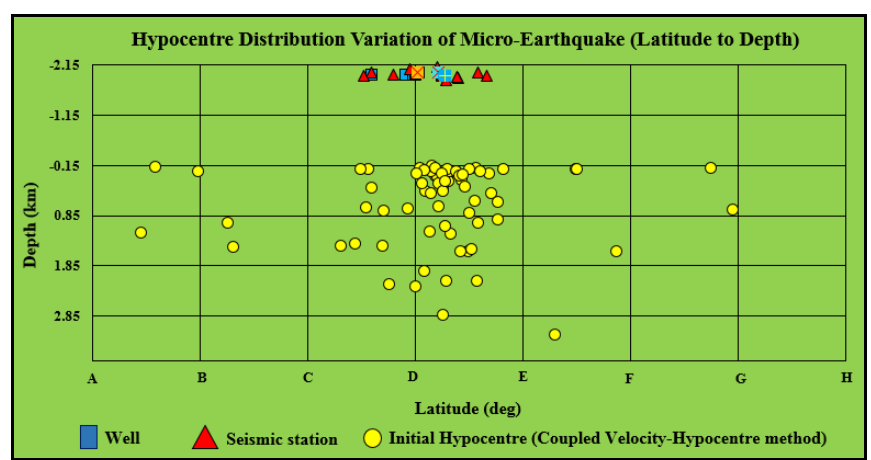

Fig. 12 Hypocenters distribution variations of micro-earthquakes (latitude to depth) on X geothermal area determined using the Coupled VelocityHypocenters method
These three parameters are essential to add because they correlate to the hypocenter location's correction horizontally and vertically (depth of the hypocenter). Fig. 10 is a map of the micro-earthquake epicenter location distribution result of the location test using the Coupled Velocity-Hypocenters method.

As many as $73 \%$ of micro-earthquake epicenter locations were concentrated in the well area (production and injection) represented by blue square symbols and recording stations represented by red triangles as illustrated in Fig. 10., whereas, $27 \%$ of micro-earthquake epicenter locations were concentrated around local faults in the study area in the northwest-southeast direction. The depth distribution of micro-earthquake hypocenter results of the location test using the Coupled Velocity-Hypocenters method has a narrower variation between $-0.02 \mathrm{~km}$ above sea level to 3.50 $\mathrm{km}$ below sea level, which is shown in Fig. 11 and Fig. 12.

Based on the test results of the distribution of the location of the micro-earthquake hypocenter using the Coupled Velocity-Hypocenters method, $73 \%$ of the micro-earthquake hypocenter was concentrated just below the well area which is a production well with a depth of $\pm 2 \mathrm{~km}$ from the lip of the well. As for the micro-earthquake hypocenter, the Geiger method's location test results spread with depths that vary between $-2 \mathrm{~km}$ above sea level to $17.85 \mathrm{~km}$ below sea level. The micro-earthquake epicenter location of the location test results using the Coupled Velocity-Hypocenters method was more concentrated in the production well area and injection area of the study area compared to the hypocenter location distribution of the location test results using the Geiger method.

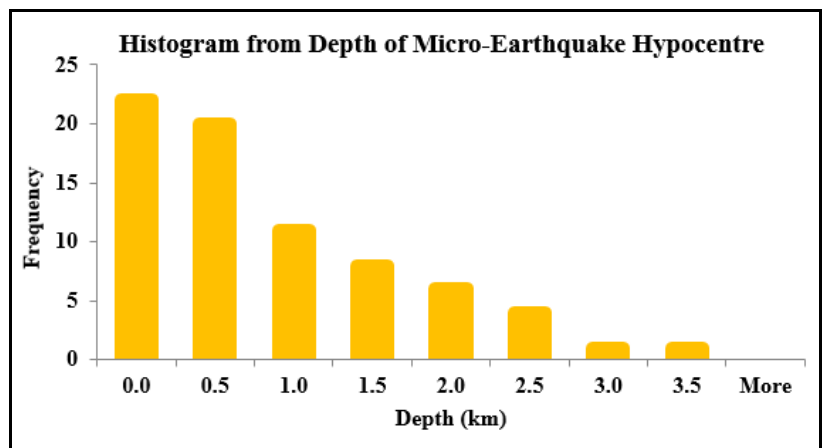

Fig. 13 Histogram depth of micro-earthquake hypocenter location test results using the Coupled Velocity-Hypocenters method

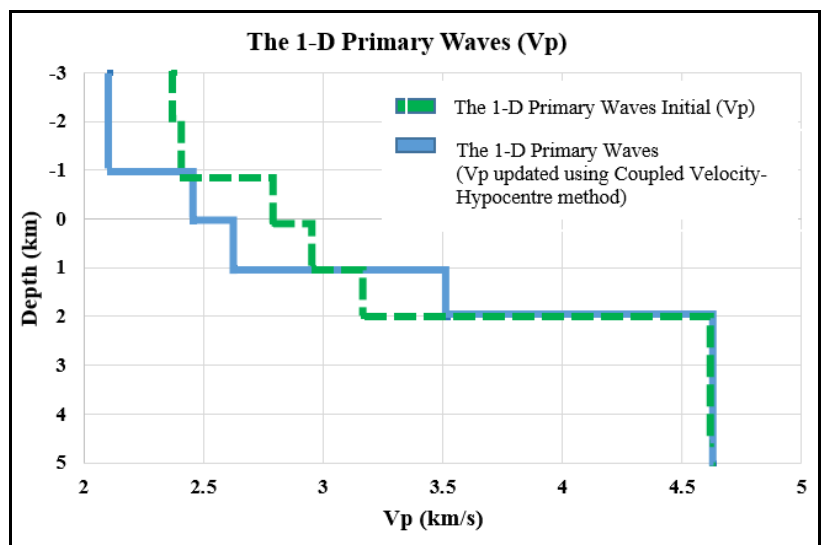

Fig. 14 The 1-D Primary (P) waves velocity initials model of research and updated 1-D of $\mathrm{P}$ waves velocity model of research 
The Coupled Velocity-Hypocenters method obtained the location of the hypocenter and the 1-D velocity model of the $\mathrm{P}$ waves of the study area, as shown in Fig. 14. Meanwhile, the location test's RMS error value using the Coupled Velocity-Hypocenters method was better than the Geiger method. RMS error values varied from 0.05 seconds to 0.75 seconds, with an average RMS error of 0.19 seconds as in Fig. 15.

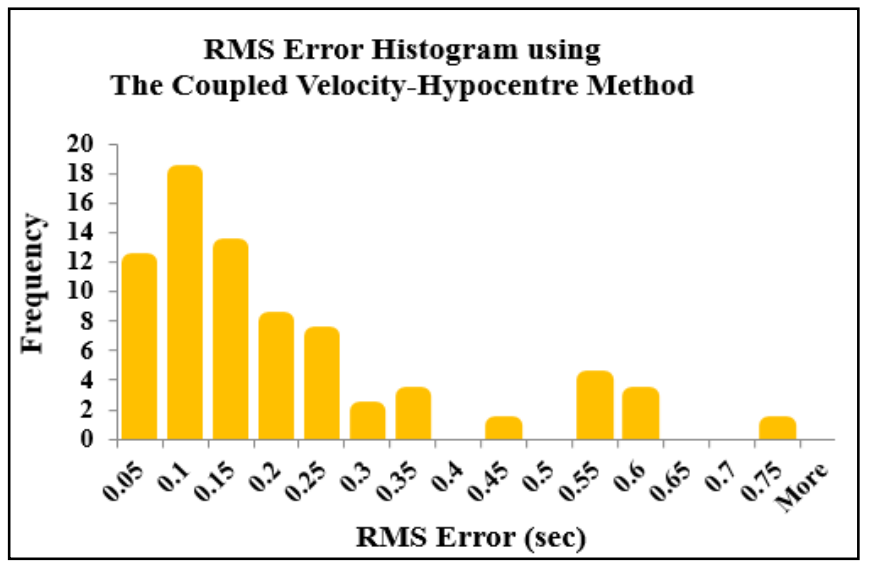

Fig. 15 RMS error histogram of micro-earthquake hypocenter determined using the Coupled Velocity-Hypocenters method

The result indicates that microearthquake hypocenter around $\mathrm{X}$ geothermal area happened due to reservoir activity in the production well or around the heat source area. The fluid activity is flowing through the fracture from the permeable zone in the heat source area, indicating the contact between cold water with high-temperature igneous rocks (heat source). The control of these two methods complies with the study area's conditions and the minimum error value (RMS error). RMS error is the residual or the difference between the recording time and the calculation time. The smaller the RMS error (near zero), the better.

\section{CONCLUSION}

The distribution of micro-earthquake hypocenter around the $\mathrm{X}$ geothermal area using Coupled Velocity-Hypocenter (with several corrected parameters such as 1-D of $\mathrm{P}$ waves velocity model, origin time, micro-earthquake hypocenter coordinates, station correction) provides a better result compared to Geiger method. This result is supported by the Coupled Velocity-Hypocenters method's average RMS error value, which was smaller, only 0.19 seconds, compared to the Geiger method, which had an average RMS error of 0.74 seconds. The micro-earthquake hypocenter location of the location test results using the Coupled Velocity-Hypocenters method was more concentrated in the reservoir area in the production well which indicates the presence of fluid flow through the fracture of the permeable zone. The microearthquake hypocenter location was also concentrated in the heat source area, which was suspected to occur due to cold water contact with temperature igneous rocks height (heat source) on the $\mathrm{X}$ geothermal area.

\section{ACKNOWLEDGEMENT}

We would like to thank PT Geo Dipa Energi (Persero) for permission to use the data in this research.

\section{REFERENCES}

[1] W. I. Sevilla, L. A. Jumawan, C. J. Clarito, M. A. Quintia, A. A Dominguiano, and R. U. Solidum, "Improved 1D velocity model and deep long-period earthquakes in Kanlaon Volcano, Philippines: Implications for its magmatic system," J. Volcanol. Geotherm. Res., vol. 393, p. 106793, 2020, doi: 10.1016/j.jvolgeores.2020.106793.

[2] M. Zhang, W. L. Ellsworth, and G. C. Beroza, "Rapid Earthquake Association and Location," Seismol. Res. Lett., vol. 90, no. 6, pp. 2276-2284, 2019, doi: 10.1785/0220190052.

[3] V. Midzi, T. Pule, B. Manzunzu, T. Mulabisana, B. S. Zulu, and S. Myendeki, "Improved earthquake location in the gold mining regions of south africa using new velocity models," South African J. Geol., vol. 123 , no. 1, pp. 35-58, 2020, doi: 10.25131/sajg.123.0008.

[4] E. Karasözen and B. Karasözen, "Earthquake location methods," GEM - Int. J. Geomathematics, vol. 11, no. 1, 2020, doi: 10.1007/s13137-020-00149-9.

[5] H. Kianimehr, E. Kissling, F. Yaminifard, and M. Tatar, "Regional minimum 1-D P-wave velocity model for a new seismicity catalogue with precise and consistent earthquake locations in southern Iran," $J$. Seismol., vol. 22, no. 6, pp. 1529-1547, 2018, doi: 10.1007/s10950018-9783-4.

[6] K. I. Konstantinou, "Estimation of optimum velocity model and precise earthquake locations in NE Aegean: Implications for seismotectonics and seismic hazard," J. Geodyn., vol. 121, pp. 143154, 2018, doi: 10.1016/j.jog.2018.07.005.

[7] I. Madrinovella, S. Widiyantoro, A. Dian, and H. Triastuty, "Studi Penentuan dan Relokasi Hiposenter Gempa Mikro Sekitar Cekungan Bandung," J. Geofis., vol. 13, no. 2, pp. 80-88, 2012.

[8] S. A. Garini, Madlazim, and E. Rahmawati, "Relokasi Hiposenter Gempa Bumi di Sulawesi Tengah dengan menggunakan Metode Geiger dan Coupled Velocity-Hypocenter," J. Fis., vol. 03, no. 02, pp. 107-112, 2014

[9] M. Liu, M. Zhang, W. Zhu, W. L. Ellsworth, and H. Li, "Rapid Characterization of the July 2019 Ridgecrest, California, Earthquake Sequence from Raw Seismic Data Using Machine-Learning Phase Picker," Geophys. Res. Lett., vol. 47, no. 4, pp. 0-2, 2020, doi: 10.1029/2019GL086189.

[10] A. Hijriani, D. P. Sahara, A. D. Nugraha, I. Ramadhan, and R. P. Sidik, "Peningkatan Akurasi Lokasi Gempa Mikro Dengan Menggunakan Metoda Double-Difference Dan Korelasi Silang Master Waveform," J. Geofis., vol. 15, no. 1, p. 21, 2017, doi: 10.36435/jgf.v15i1.33.

[11] K. Nishi, "Hypocenter Calculation Software GAD (Geiger's method with Adaptive Damping)," vol. 1, no. May. pp. 1-5, 2005.

[12] E. Kissling, Program VELEST User Guide, no. October. 1995.

[13] N. K. T. Suandayani and S. Poniman, "Penentuan Nilai Magnitudo Gempa Vulkanik Gunung Guntur Jawa Barat berdasarkan Data Seismik," 2017.

[14] S. G. Halida, "Relokasi Hiposenter dan Koreksi Stasiun MEQ menggunakan Metode Coupled Velocity-Hypocenter," Surabaya, Indonesia, 2019.

[15] N. A. A. Siregar, "Penentuan Lokasi Hiposenter Gempa Bumi Mikromenggunakan Metode Geiger dengan Arrival Times P- Wave dan S- Wave Berdasarkan S-Transform," Surabaya, Indonesia, 2019.

[16] A. F. Akbar et al., "Study on Seismicity and Seismic Tomography on a Hydrothermal System in West Java," World Geotherm. Congr. 2015, Melbourne, Aust., no. April, pp. 1-5, 2015. 